\title{
The Isolation of Myristicin from Nutmeg Oil by Sequences Distillation
}

\author{
Susana Elya Sudradjat ${ }^{1,2^{*}}$, Kris Herawan Timotius², Abdul Mun'im³, Effionora Anwar ${ }^{*}$ \\ ${ }^{1}$ Faculty of Pharmacy, Universitas Indonesia, Depok, West Java, INDONESIA. \\ 2 Department of Herbal Medicine, Faculty of Medicine Universitas Kristen Krida Wacana, Jakarta, INDONESIA. \\ ${ }^{3}$ Department of Pharmacognosy -Phytochemistry, Faculty of Pharmacy, Universitas Indonesia, Depok, West Java, INDONESIA.
}

\begin{abstract}
Background: Nutmeg oil is used in Asia as a traditional medicine for a stomach cramps, diarrhea, and insomnia. It's quality need to be improved by increasing myristicin content. Objectives: This study aimed to increase the myristicin content of nutmeg oil by sequences distillations. Methods: Three different conditions of distillations were applied sequentially. The first, second and third distillation were at $110{ }^{\circ} \mathrm{C}\left(0.2\right.$ bars), $105{ }^{\circ} \mathrm{C}(1 \mathrm{bar})$, and $145{ }^{\circ} \mathrm{C}$ (0.2 bars) respectively. Myristicin contents determined by gas chromatography-mass spectrometry (GC-MS). Results: the myristicin content of the original nutmeg oil, the first, the second, and the third distillation were $12.93 \%, 17.50 \%, 54.21 \%$, and $83.45 \%$ respectively. The total yield of the final product resulted after the third distillation was $5.84 \% \mathrm{v} / \mathrm{v}$ from the original oil. Conclusion: The use of sequences distillation with
\end{abstract}

a different condition can increase the myristicin content from the original nutmeg oil.

Key words: Nutmeg oil, Myristicin, Sequences distillation, GC-MS.

Correspondence

Susana Elya Sudradjat, Effionora Anwar, Faculty of Pharmacy, Universitas Indonesia, Depok 16424, West Java, INDONESIA. Department of Herbal Medicine, Faculty of Medicine Universitas Kristen Krida Wacana, Jakarta, INDONESIA.

Phone: +62 878-8000-7136, 62 878-8000-7136

Email: effionora@farmasi.ui.ac.id, susanasudrajat_09@yahoo.com

DOI: 10.5530/jyp.2018.10.6

\section{INTRODUCTION}

The seed and mace of nutmeg are the product of the same plant that is Myristica fragrans Houtt from the Myristicaceae family. This plant is originally from the Moluccas and now is widely grown in eastern India, the Caribbean, and Grenada. Since a long time ago this nutmeg has been used as a spice and, medicine. ${ }^{1}$ Myristicin is psychoactive substance and one of the main constituents of nutmeg oil. Myristicin content in plant organs varies, depending on growing and storage condition. ${ }^{2}$

\section{Myristicin}

Myristicin (4-methoxy-6-(2-propenyl)1,3-benzodioxole; Figure 1) is a major compound of the essential oil of seeds and mace nutmeg. ${ }^{1}$ Nutmeg poisoning is rare but should be considered in drug abuse. ${ }^{3}$ The increased of the use of myristicin as a hallucinogen is because it is cheap and this often causes fatal cases of poisoning due to myristicin. ${ }^{4}$ We can also find myristicin in fennel, celery, and parsley plants. ${ }^{5}$ Myristicin is also potential as an effective chemoprotective agent against cancer and hepatoprotective activity. ${ }^{6,7}$ Myristicin is a derivative of phenylpropanoid compounds, in the form of a clear liquid, not soluble in water but soluble in organic solvents. It smells like spices, and the aroma is sharp and easily vaporized. Myristicin is the primary aromatic compound of the volatile of nutmeg oil, derived from the dried ripe seed of $M$. fragrans. Nutmeg from the Moluccas contain 5.57-13.76\% myristicin. ${ }^{8}$

There are various ways to isolate myristicin, among others; distillation, extraction, and column chromatography. ${ }^{9}$ The method that is most widely used to separate myristicin is by distillation. The advantage of this simple method is that it doesn't need organic solvents and it has high concentration result. ${ }^{10}$ Nutmeg oil has the various compound with different boiling points. Distillation is the process of separating the compounds of a mixture comprising two or more liquids based on having different vapor pressure or boiling points. The essential oil compounds are not stable at high temperatures. To obtain the high-grade nutmeg oil, it is necessary to conduct distillation at low temperature under certain pressure. According to Guenther (1987), at $15 \mathrm{~mm} \mathrm{Hg}$, the boiling point of myristicin is $149.5^{\circ} \mathrm{C}$. The aim of this distillation process is to find the appropriate temperature for obtaining the highest concentration of myristicin in the nutmeg oil. The distillation pressure used in this distillation was applied to decrease the boiling point of myristicin significantly to prevent the decomposition on myristicin. ${ }^{11}$

GCMS is the coupling of the gas chromatograph with the mass spectrometer. The often use of GCMS is because it is a well-established technique to analyze the essential oils. This analysis often used is due to the development of easy-to-handle robust system concerning sensitivity and relatively low cost. The complex compounds can be analyzed in detail by spectral interpretation of the separated compounds because of the on-line coupling of a chromatographic device to a spectrometer. ${ }^{12}$

The sequences distillation isolated myristicin and separated the components by different boiling points. In this case, it is important to know the boiling point of each compound.

\section{MATERIAL AND METHODS}

\section{Material}

In this research, we obtained the nutmeg oil from Balittro (Balai Penelitian Tanaman Rempah dan Obat) Bogor, West Java.

\section{Method}

\section{The Sequences Distillations Method}

The sequences distillations in three stages at different temperature and vacuum/pressures are as diagramed in Figure 2. The products of each step were named isolate (1), isolate (2), and isolate (3) respectively. The 
analyses of the nutmeg oil sample and the isolates is by Gas chromatography-mass spectrophotometry (GC-MS).

Distillation (1)

The distillation of one hundred and fifty $\mathrm{ml}$ nutmeg oil is for approximately $1 \mathrm{~h}$ of 0.2 bars at $110^{\circ} \mathrm{C}$. The volume of the isolate (1) and distillate (1) is measured and then is tested by GC-MS.

Distillation (2)

The distillation of twenty $\mathrm{ml}$ isolates (1) mixed with $200 \mathrm{ml}$ of $5 \% \mathrm{NaCl}$ solution is for $2 \mathrm{~h}$ of $1 \mathrm{bar}$ at $105^{\circ} \mathrm{C}$.

The volume of the isolate (2) and distillate (2) is measured and then tested by GC-MS.

Distillation (3)

One hundred and fifty $\mathrm{ml}$ isolate (2) is distilled approximately for $1 \mathrm{~h}$ of 0.2 bars at $145{ }^{\circ} \mathrm{C}$. The volume of the residue and isolate (3) is measured and then tested by GC-MS.

\section{Gas chromatography-mass spectrophotometry (GC-MS)}

The GCMS Agilent Model 6890 equipped with Selective Mass Detector 5973 analyzed the myristicin and other compounds. The capillary column HP SMS (60-meter x $0.25 \mathrm{~mm} \times 0.25 \mu \mathrm{m})$ was directly coupled to the mass spectrophotometer. The carrier gas was helium $(1 \mathrm{ml} / \mathrm{min})$. The program used was $4 \mathrm{~min}$ isothermal at $100^{\circ} \mathrm{C}$ then $4^{\circ} \mathrm{C} / \mathrm{min}$ to $350^{\circ} \mathrm{C}$. The Wiley 9 N11L Mass Spectral Library identified the spectra.

\section{Characterization}

The quality of nutmeg oil purchased from Balittro (Balai Penelitian Tanaman Rempah dan Obat) Bogor, West Java needs to be tested, to know the percentage of its purity, color, density, and solubility in alcohol.

\section{RESULTS AND DISCUSSION}

In this research, the sequences distillations of myristicin from nutmeg oil by using two types of distillation, as follows: distillation of mixed liquid without water vapor (fractional vacuum distillation) and distillation from a mixture of a non-mixed liquid with water vapor. The difference of boiling points compounds of nutmeg oil is the base of distillation. The compounds having a low boiling point will evaporate first, whereas the compounds having high boiling points will evaporate at the end of the distillation.

The nutmeg oil from Bogor-West Java (Balitro) tested by GCMS contains 55 compounds with different retention times and levels. Twenty-one compounds have more than $0.3 \%$ concentration as shown in Table 1 . The main compounds in the oil were $a$-terpineol (15.42\%), 4-terpineol (10.77\%), myristicin (12.93\%), a-terpinolene (9.77\%), and $\alpha$-terpinen (6.09\%). This research showed that the nutmeg oil has a high quality because of its a high percentage of active compounds. On distillation (1), nutmeg oil from Bogor distilled at 0.2 bars and temperature of $110^{\circ} \mathrm{C}$ for approximately $1 \mathrm{~h}$ produces distillate (1) and isolate (1). Terpene compounds having a low boiling point will evaporate first. Therefore, these compounds are called the light fraction of nutmeg oil. This terpene is the dominant compound about $80 \%$ of nutmeg oil. The range of the terpenes boiling point compounds is about $150-180{ }^{\circ} \mathrm{C}$ at 1 bar. At a pressure below 1 bar, the boiling point range will become lower. Myristicin is one of the terpene-o compound having the high boiling point, so it evaporates at the end of the distillation. The order of the evaporation of the distillation is shown in Figure 2. GC-MS analyzed the compounds in distillate and isolate. Distillate (1) contains the compounds which have a lower boiling point than myristicin such as $\beta$ pinene, dl-limonene, 1,8-cineole, camphene, and $\alpha$-terpinolene.

On distillation (1), nutmeg oil from Bogor distilled at a pressure of 0.2 bars and a temperature of $110{ }^{\circ} \mathrm{C}$ for approximately $1 \mathrm{~h}$ produces distillate (1) and isolate (1). The volume of the isolate (1) is $80.9 \mathrm{ml}$ that containing $17.50 \%$ myristicin. At this step, there is an increase myristicin level of nutmeg oil from $12.93 \%$ to $17.50 \%$. There are still other compounds besides the myristicin, such as a-terpineol, diethyl phthalate, 4-terpineol, $\alpha$-terpinolene and phenol, 2,6-dimethoxy-4-(2-propenyl). We must remove the other compound except for myristicin. The results obtained from the distillation (1) will become the material for distillation (2) with $\mathrm{NaCl}$ solution.

On distillation (2), we distill the mixed isolate (1) with $5 \% \mathrm{Na} \mathrm{Cl}$ solution at $105{ }^{\circ} \mathrm{C}$ of 1 bar for $2 \mathrm{~h}$. The addition of $\mathrm{Na} \mathrm{Cl}$ solution into the system is intended to increase the boiling point of water because only $\mathrm{Na} \mathrm{Cl}$ will dissolve in the water. The principle used in this process is the purification of the compounds by utilizing the other compounds which have a lower boiling point. In this case, the distillation process follows the Dalton laws for partial pressure, stating that if two or more gas or steam that does not react at a constant temperature, each gas will produce the same pressure whether it is alone or mixed. This law means that the temperature of the boiling point will be lower than the boiling point of a volatile compound. In this research, the used of $\mathrm{Na} \mathrm{Cl}$ solution is because it has a lower boiling point than that of the other compounds. Thus, the boiling point of the mixture will be lower than that of the boiling point of a $\mathrm{Na} \mathrm{Cl}$ solution at normal temperature. The process of steam distillation is very beneficial because it can reduce the destruction of the material due to its contacts with heat (Guenther, 1987). ${ }^{9}$ The measurement of the densities is in Table 3. The high density of the isolate is because of the decline of terpene contents in the oil and causes the remains in the heavy isolate fraction.

\begin{tabular}{|c|c|}
\hline Compounds & Contents (\%) \\
\hline \multicolumn{2}{|c|}{ Monoterpene hydrocarbons } \\
\hline$\beta$-pinene & 0.50 \\
\hline a-terpinene & 6.09 \\
\hline p-cymene & 4.11 \\
\hline dl-limonene & 4.73 \\
\hline$\gamma$-terpinene & 4.05 \\
\hline a-terpinolene & 9.77 \\
\hline \multicolumn{2}{|l|}{ Oxides } \\
\hline 1,8-Cineole & 3.53 \\
\hline \multicolumn{2}{|c|}{ Sesquiterpene hydrocarbons } \\
\hline a-copaene & 1.05 \\
\hline Caryophyllene & 0.55 \\
\hline \multicolumn{2}{|l|}{ Aromatics } \\
\hline Safrole & 1.94 \\
\hline Eugenol & 0.33 \\
\hline trans-Isoeugenol & 0.51 \\
\hline Myristicin & 12.93 \\
\hline Elemicin & 0.36 \\
\hline \multicolumn{2}{|c|}{ Monoterpene alcohols } \\
\hline D-fenchyl alcohol & 2.84 \\
\hline Terpinene 1-ol & 4.35 \\
\hline$\beta$-Terpineol & 2.42 \\
\hline Isoborneol & 1.37 \\
\hline 4-terpineol & 10.77 \\
\hline a-Terpineol & 15.42 \\
\hline \multicolumn{2}{|l|}{ Esters } \\
\hline Bornyl acetate & 0.31 \\
\hline
\end{tabular}


The next compound that will evaporate is terpene-o compounds that have higher boiling points than that of the others. Myristicin has a high boiling point, so it evaporates at the end of the distillation process. The order of the evaporation of the distillation is in Figure 2. On distillation (2) with additional $\mathrm{Na} \mathrm{Cl}$ solution into the system is to increase the boiling point of water so that the light compounds will evaporate and increase the level of myristicin in an isolate (2). Distillation (2) produces isolate containing $54.21 \%$ myristicin, $31.58 \%$ diethyl phthalate and $4.01 \%$ phenol,2,6-dimethoxy-4-(2-propenyl). The boiling point of diethyl phthalate at 1 bar is $299^{\circ} \mathrm{C}$ while the boiling point of myristicin is 276.5 ${ }^{\circ} \mathrm{C}$ and the boiling point of phenol,2,6-dimethoxy-4-(2-propenyl) is $296.51{ }^{\circ} \mathrm{C}$. If we want to get myristicin with higher purity, it is needed to be isolated from diethyl phthalate and phenol,2,6-dimethoxy-4-(2propenyl) by distillation (3).

Distillation (3) is done approximately for $1 \mathrm{~h}$ at 0.2 bars and temperature of $145^{\circ} \mathrm{C}$. Since the boiling point of myristicin is lower than the boiling point of diethyl phthalate, the myristicin is removed into a distillate (3) while the diethyl phthalate is still in the residue. The vacuum pressure used is to lower the boiling point of myristicin. The decrease of the boiling point is significant to prevent the decomposition of myristicin. This temperature distillation at $145^{\circ} \mathrm{C}$ is due to reduce the compounds of higher terpenes and to increase the levels of myristicin. The range of the densities of the isolates is in Table 3. The results indicate that the higher the temperature of the distillation the weigher the density is. The process of distillation (3) is to improve the levels of myristicin by separating it from the light fractions of nutmeg oil. Thus, the isolation or purification of myristicin is easier and faster.

Table 4 provides different characteristics of nutmeg oil and isolates. This table indicates that there are considerable changes in characteristics of the oil after distillation at $145^{\circ} \mathrm{C}$. This increase is due to the decline of the light fraction or the terpene compounds in the oil. Also, the reduced levels of terpenes in oil affect the higher density of oil. In this case, the lower pressure is done to reduce the polymerization that causes the increase of long carbon chains. In general, the efficiency of tools, time and temperature of distillation influenced the result of fraction randemen. The higher the efficiency of the device the higher the result is.

Overall, the concentration of myristicin increased at each stage of distillation, starting from nutmeg oil in distillation (1) to distillation (2). Increased levels of myristicin can be seen in Table 4. Distillation (1) produces $17.50 \%$ myristicin, distillation (2) produce $54.21 \%$ myristicin, and distillation (3) produce $83.45 \%$ myristicin.

Isolate (3) contains $83.45 \%$ myristicin and $4.01 \%$ phenol,2,6-dimethoxy4-(2-propenyl). Phenol,2,6-dimethoxy-4-(2-propenyl) is used as food additives. This material is used at the maximum of $5 \mathrm{ppm}$, to add the scent of smoke and to preserve the food (meat, fish, etc.).

\begin{tabular}{|c|c|c|c|c|c|}
\hline Compounds & $\begin{array}{l}\text { Retention time } \\
\quad(\min .)\end{array}$ & Nutmeg oil (\%) & $\begin{array}{c}\text { Isolate } 1 \\
\text { (\%) }\end{array}$ & $\begin{array}{c}\text { Isolate } 2 \\
(\%)\end{array}$ & $\begin{array}{c}\text { Isolate } 3 \\
(\%)\end{array}$ \\
\hline a-terpineol & 10.171 & 15.42 & 12.81 & - & - \\
\hline myristicin & 14.309 & 12.93 & 17.50 & 54.21 & 83.45 \\
\hline diethyl phthalate & 14.967 & 4.56 & 8.67 & 31.58 & 0.17 \\
\hline 4-terpineol & 9.977 & 10.77 & 9 & - & - \\
\hline a-terpinolene & 8.787 & 9.77 & 7.83 & 0.17 & 0.17 \\
\hline a-terpinene & 7.972 & 5.48 & - & - & - \\
\hline phenol, 2,6-dimethoxy-4-(2-propenyl) & 15.012 & 0.39 & 1.06 & 4.01 & 4.01 \\
\hline
\end{tabular}

\begin{tabular}{|c|c|c|c|c|}
\hline Characteristics & Nutmeg oil & Isolate (1) & Isolate (2) & Isolate (3) \\
\hline Color & Light yellow & Dark yellow & Light brown & Colorless \\
\hline Density & 0.913 & 1.12 & 1.15 & 1.15 \\
\hline Odor & Aromatic & Over powering & Over powering & Light \\
\hline $\begin{array}{l}\text { Solubility } \\
\text { in alcohol }\end{array}$ & 1:1 & $1: 1$ & $1: 1$ & $1: 1$ \\
\hline
\end{tabular}

Table 4 : The increasing levels of myristicin

\begin{tabular}{|c|c|c|c|c|c|}
\hline Stage & Material & $\begin{array}{c}\text { Myristicin } \\
(\%, \mathrm{w} / \mathrm{v})\end{array}$ & Volume (ml) & $\begin{array}{c}\text { Yield } \\
(\mathrm{g})\end{array}$ & $\begin{array}{c}\text { Percentage } \\
(\%)\end{array}$ \\
\hline & Nutmeg oil & 12.93 & 150 & 19.35 & 100 \\
\hline Distillation 1 & Isolate1 & 17.50 & 80.9 & 14.16 & 73 \\
\hline Distillation 2 & Isolate 2 & 54.21 & 24 & 13.01 & 67 \\
\hline Distillation 3 & Isolate 3 & 83.45 & 7 & 5.84 & 30 \\
\hline
\end{tabular}




\begin{tabular}{ccccc}
\hline Table 5 : The compounds of isolate (3) identified by GCMS. & & & \\
\hline Compound & $\begin{array}{c}\text { Retention time } \\
\text { (minute) }\end{array}$ & $\begin{array}{c}\text { Area } \\
(\%)\end{array}$ & Molecular Weight & $\begin{array}{c}\text { Boiling point } \\
\left({ }^{\circ} \mathrm{C}\right)\end{array}$ \\
\hline Myristicin & 14.309 & 83.45 & 192.2 & Molecule Structure \\
$\begin{array}{c}\text { Phenol, 2,6-imethoxy-4-(2- } \\
\text { propenyl) } \\
\text { (food additive) }\end{array}$ & 15.102 & 4.01 & 194.23 \\
\hline
\end{tabular}

Note : The other compound does not mention above are lower than $4 \%$

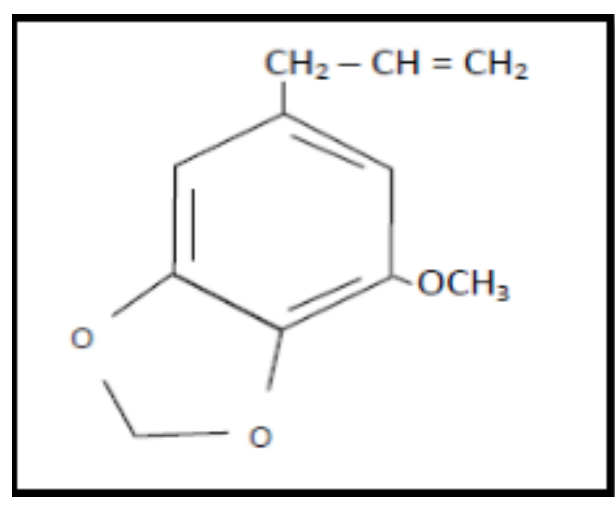

Figure 1 : The molecular structure of myristicin.

Source: Barceloux, 2009, it has been modified.

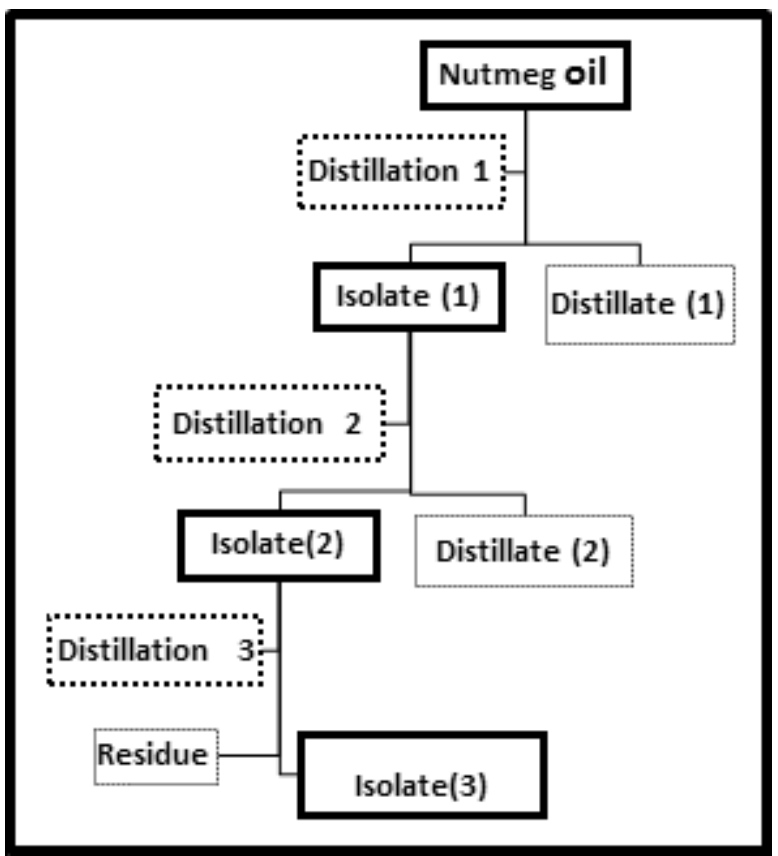

Figure 2 : The sequences distillation diagram.

\section{CONCLUSION}

The isolation of myristicin from nutmeg oil by sequences distillation according to the GC-MS analysis increase from $5.84 \%$ to $83.45 \%$ concentration.

\section{ACKNOWLEDGMENT}

This study was supported by Directorate of Research and Community Service (DRPM) Universitas Indonesia via a grant "Hibah Publikasi Internasional Terindeks Untuk Tugas Akhir Mahasiswa Universitas Indonesia (Pitta)" 2017.

\section{CONFLICT OF INTEREST}

There is no conflict of interest.

\section{ABBREVIATION USED}

GC-MS: Gas chromatography-mass spectrophotometry; h: hour; $\mathbf{N a ~ C l : ~}$ Sodium Chloride.

\section{REFERENCES}

1. Barceloux DG. Nutmeg (Myristica fragrans Houtt.). Medical Toxicology of Natural Substances: Foods, Fungi, Medicinal Herbs, Toxic Plants, and Venomous Animals.; Hoboken, NJ. John Wiley and Sons; 2009.p.373-9.

2. Hallstrom H, Thuvander A. Toxicological Evaluation of Myristicin, Natural Toxins. 1997;5(5):186-92

3. Demetriades A, Wallman PD, McGuiness A, Gavalas MC. Low cost, high risk accidental nutmeg intoxication. Emerg Med J. 2005;22(3):223-5.

4. Rahman NAA, Fazilah A, Effarizah M. Toxicity of nutmeg (Myristicin): A Review. Int J Adv Sci Eng Inf Technol. 2015;5(2):212-5

5. Yang $\mathrm{AH}, \mathrm{He}$ X, Chen JX, He LN, Jin CH, Wang LL, et al. Identification and characterization of reactive metabolites in myristicin-mediated mechanism-based inhibition of CYP1A2. Chem. Biol Interactions. 2015;237:133-40.

6. Carvalho AA, Andrade LN, Vieira EB, Pergentino D. Antitumor phenylpropanoids found in essential oil. BioMed Res Inter. 2015;1-20.

7. Morita T, et al. Hepatoprotective Effect of Myristicin from Nutmeg (Myristica fragrans) on Lipopolysaccharide/D-Galactosamin-Induced Liver Injury. J Agric Food Chem. 2003;51(6):1560-5.

8. Marzuki I, Joefrie B, Aziz SA, Agusta H, Surahman M. Physico-Chemical Characterization of Maluku Nutmeg Oil. IJSE. 2014;7(1);61-4.

9. Al-Jumaily EF, Al-Amiry MHA. Extraction and purification of terpenes from nutmeg (Myristica fragrans). JUNS. 2012;15(3):151-60.

10. Suprihatin, Ketaren S, Ngudiwaluyo S, Friyadi A. Isolation of Myristicin From Nutmeg Oil with steam distillation method. J Tek Ind. Pert. 1968;23-28.

11. Guenther E. Essential oils. Ketaren S, editor. Universitas Indonesia, Jakarta Indonesia. 1987;1.

12. Baser KH, Buchbauer G. Handbook of essential oils: science, technology, and applications. London NewYork. CRC Press; 2010. P. 3-39.

Article History: Submission Date : 31-07-2017 ; Revised Date : 21-09-2017; Acceptance Date : 04-11-2017.

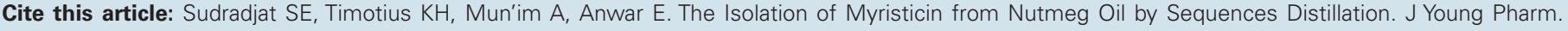
2018;10(1):20-3. 